\title{
Macroarray Detection of Eleven Potato-Infecting Viruses and Potato spindle tuber viroid
}

\author{
Bright Agindotan and Keith L. Perry, Department of Plant Pathology, Cornell University, Ithaca, NY 14853
}

\begin{abstract}
Agindotan, B., and Perry, K. L. 2008. Macroarray detection of eleven potato-infecting viruses and Potato spindle tuber viroid. Plant Dis. 92:730-740.

A macroarray was developed for the detection of 11 potato viruses and Potato spindle tuber viroid. The 11 viruses detected included those commonly found or tested for in North American potato seed certification programs: Alfalfa mosaic virus, Cucumber mosaic virus, Potato mop top virus, Potato leafroll virus, Potato latent virus, Potato virus $A$, Potato virus $M$, Potato virus $S$, Potato virus $X$, Potato virus $Y$, and Tobacco rattle virus. These viruses were detected using oligonucleotide 70-mer probes and labeled targets prepared by a random primed amplification procedure. Potato plants analyzed included those infected with 12 reference virus stocks and 36 field isolates. Results from the macroarray were entirely consistent with those obtained using a standard serological assay (enzyme-linked immunosorbent assay). Four isolates of Potato spindle tuber viroid, in mixed infection with one or more viruses, also were detected in the array, although strong hybridization signals required amplification with viroid-specific primers in combination with anchored-random primers. In individual plants, up to four viruses, or a viroid plus two viruses, were detected, with no apparent competition or inhibition. Macroarrays are a cost-effective approach to the simultaneous diagnostic detection of multiple pathogens from infected plants.
\end{abstract}

The diagnoses of diseases caused by viruses or virus-like agents in plants have long been a challenge, because the effects of plant viruses on host growth is often nondescript (e.g., stunting, growth malformations, and yellowing); hence the development of bioassays, including host range and symptoms, and serological or biophysical assays to detect virus-encoded proteins or nucleic acids (16). More recently, polymerase chain reaction (PCR)based detection methods have provided a remarkable degree of sensitivity, while serological techniques continue to be the methods of choice in less specialized settings and in the commercial diagnostics sector (24). Each technique has its own specific limitations; for instance, with serological assays, one must have access to antibodies and these must be robust and recognize all isolates of a virus species. Hybridization assays, when properly designed and executed, can provide both excellent sensitivity and the robust detection of many (all) isolates though, historically, this has been dependent on the availability of purified viral nucleic acids or recombinant DNA clones thereof. An attractive and practical alternative has been

Corresponding author: K. L. Perry

E-mail: KLP3@cornell.edu

Accepted for publication 18 December 2007.

doi:10.1094/PDIS-92-5-0730

(C) 2008 The American Phytopathological Society to synthesize virus-specific (complementary) DNAs $(1,7,11,17,18,23,33)$. When viral genomic sequences are available, the only limitations in this approach are the costs associated with oligonucleotide synthesis, arrays, and reagents. Pathogenspecific oligonucleotides form the foundation for the development and utilization of array-based detection systems.

Though microarrays originally were developed for studies of gene discovery and expression, analysis of single-nucleotide polymorphisms, and DNA sequencing (among other applications; 26), those interested in diagnostics quickly recognized the potential of this technology for identifying pathogens. Arrays were developed to differentiate bacterial species and antibiotic resistance phenotypes (32) and to identify prokaryotic, eukaryotic, and viral pathogens on a single microarray (36). Although many arrays have been developed to detect species and strains within a limited group of pathogens, perhaps the most remarkable application of this technology has been the development of a microarray for the detection and genotyping of all known viruses with fully sequenced genomes (33). This 'pan-viral' microarray or 'Virochip' was used in the original identification of a severe acute respiratory syndrome (SARS) coronavirus and contained oligonucleotide probes for over 1,000 viruses $(9,34)$.

Arrays also have been developed for the detection of plant pathogens, the earliest of which were for the identification and differentiation of oomycetes (21). These were low-density, membrane-based macroarrays, originally described as reverse dot blots $(21,27)$. Refinements in these macroarrays are exemplified by arrays for differentiating Pythium spp. (31) and for detecting bacterial pathogens of potato (12), vascular wilt pathogens of tomato (22), apple pathogens (28), and viruses (2). Glass-slide-based microarrays for pathogen detection have been employed in work with a nematode (13) and a chytrid (1), but the majority of the applications have been in detecting plant viruses $(11,20)$, especially those of potato $(1,4,6,7)$.

Thus far, the microarrays for plant pathogen detection have been of relatively low density and have not taken full advantage of the power of the technology. One of the obstacles has been the high costs associated with their use. An attractive alternative has been membrane-based macroarrays, the use of which does not involve specialized equipment or particularly costly reagents or materials. Of practical significance, macroarrays based on nylon membranes can be reused many times, more than 20 in our work (2). The reuse of membranes offers a huge cost reduction relative to single-use microarray technologies. As efforts are made to develop macroarrays for scores of viruses and multiple pathogens, a limiting factor will be the number of probes that can be accommodated per membrane. The replica pin spotting technology with a 384-pin device will allow for 1,536 spots per unit size nylon membrane (the size of a 96-well microtiter plate); 1,536 spots will be satisfactory for many arrays, in particular those targeting pathogens of a specific crop.

There were two underlying objectives of this study. The first was to fabricate and validate a macroarray for the detection of plant viruses and a viroid normally screened for in North American potato seed certification programs. The second was to build upon previous work in establishing methodologies (2), with the ultimate goal of developing a multipathogen detection system for prokaryotic, oomycete, fungal, and viral pathogens of solanaceous crop plants.

\section{MATERIALS AND METHODS}

Plant materials, viruses, and serological testing. All viruses and Potato spindle tuber viroid (PSTVd) were from potato (Solanum tuberosum) tissue culture plantlets maintained in the Cornell University in vitro culture collection (30), except where 
noted. The 11 viruses studied were Alfalfa mosaic virus (AMV), Cucumber mosaic virus (CMV), Potato mop-top virus (PMTV), Potato leafroll virus (PLRV), Potato latent virus (PotLV), Potato virus A (PVA), Potato virus $M$ (PVM), Potato virus $S$ (PVS), Potato virus $X$ (PVX), Potato virus $Y$ (PVY), and Tobacco rattle virus (TRV).

The infected potato cultivars used as standards for enzyme-linked immunosorbent assay (ELISA) and macroarray detection of specific viruses are listed in Table 1. Infected potato cultivars (accessions) screened for viruses are shown in Table 2 . Purified PMTV-infected plant RNA extracts were kindly provided by Dr. Jari Valkonen and Johnanna Aura, Department of Applied Biology, Helsinki University, Finland. The PMTV isolate Oleva is from potato in Norway provided by Dr. Carl Spetz; it was propagated in Nicotiana benthamiana. The PMTV isolate Van Gogh is from naturally infected tubers of $S$. tuberosum cv. Van Gogh in Finland and was provided by Dr. Satu Latvala-Kilby. TRV isolates PV73 and WAI were kindly provided by Jim Crosslin (United States Department of Agriculture, Prosser, WA); TRV isolate A is from the Cornell University collection. TRV was propagated in potato cvs. Eva and Saco. PVA isolate GM is from the Schultz collection (35). PSTVd was propagated in cvs. Eva and Atlantic. Most multiple virus infections were naturally occurring but, where required, single and multiple virus or viroid infections were established by mechanical inoculation of sap extracts in $0.05 \mathrm{M}$ sodium phosphate buffer, $\mathrm{pH}$ 7.0. In order to evaluate the detection of PSTVd in the presence of multiple viruses, the stock PSTV-UF2 was grafted as a scion onto a rootstock of the potato accession Colorado Long. This resulted in a potato line propagated from the scion with PSTV-UF2, PVS, and PVX; other viruses found in Colorado Long were not detected in the scion by double-antibody sandwiched (DAS)-ELISA (see below).

For serological assays, virus-specific antibodies and reagents were obtained from Agdia Inc. (Elkhart, IN) except for the TRV-specific antibodies obtained from Neogen Europe Limited (Scotland, UK). DAS-ELISA assays were performed following the manufacturer's protocols. An antigen-coated plate or plate-trapped antigen (PTA)-ELISA (25) was used for the detection of AMV. Stem and leaf tissue from in vitro or greenhouse grown plants were homogenized in coating or extraction buffers at a dilution of 1:20 (wt/vol). Plants tissues with mean absorbance values of

Table 1. Virus and viroid isolates in potato used as standards for enzyme-linked immunosorbent assay and in the validation of the macroarray

\begin{tabular}{llll}
\hline Virus, viroid $^{\mathbf{a}}$ & Other viruses present $^{\mathbf{b}}$ & Isolate name & Potato cultivar $^{\mathbf{c}}$ \\
\hline Virus & & & \\
AMV & PVS & PI498130 & PI498130 \\
CMV & - & Mal1 & A6 \\
CMV & - & S2A & All Blue \\
PotLV & - & VTC & Red LaSoda \\
PLRV & - & \#4 & Russet Burbank \\
PLRV & - & Superior & Superior \\
PLRV & - & Kennebec & Kennebec \\
PMTV & - & Van Gogh & Van Gogh \\
PVA & PVS & J & 41956 \\
PVM & - & CO & $\ldots$ \\
PVS & - & 41956 & 41956 \\
PVX & PVS & WI & Abnaki \\
PVY & - & 1035 & $\ldots$ \\
TRV & PVX & A & Saco \\
TRV & PVX & PV73 & Saco \\
TRV & PVX & WAI & Saco \\
Viroid & & & \\
PSTVd & PVS & 1989 & $\ldots$ \\
PSTVd & PVS & UF1 & $\ldots$ \\
PSTVd & PVS & UF2 & $\ldots$ \\
PSTVd & PVS, PVX & UF2 & $\ldots$ \\
PSTVd & PVS & UF3 & $\ldots$ \\
PSTVd & - & 1989 & Eva \\
PSTVd & - & 1989 & Atlantic \\
\hline
\end{tabular}

${ }^{a}$ Reference stocks of viruses and viroids are those maintained in or introduced into cultivars of potato, except where noted. The acronyms are as follow: AMV, Alfalfa mosaic virus; CMV, Cucumber mosaic virus; PotLV, Potato latent virus; PLRV, Potato leafroll virus; PMTV, Potato mop-top virus; PVA, Potato virus A; PVM, Potato virus M; PVS, Potato virus S; PVX, Potato virus X; PVY, Potato virus $Y$; TRV, Tobacco rattle virus; PSTVd, Potato spindle tuber viroid.

${ }^{\mathrm{b}}$ Some of the reference stocks are plants infected with two viruses or virus and viroid. The reference stocks are organized by the virus for which they serve as positive controls in this laboratory; - indicates that no other virus was detected.

${ }^{\mathrm{c}}$ The cultivars are of Solanum tuberosum, except where indicated; ... denotes potato accessions for which the cultivar is not known.

d PI498130 is an accession of S. okadae. three times or greater the mean values of uninfected plants were regarded as infected.

RNA extraction, reverse transcription, and cDNA amplification. Total RNA extracts were prepared from leaf and stem tissue of in-vitro-grown potato plantlets or from greenhouse-grown plants. Extracts were prepared using the Plant RNAeasy kit (Qiagen, Inc., Valencia, CA) following the manufacturer's protocol, as described by Agindotan and Perry (2). The PMTVinfected plant RNAs were purified using both the Plant RNeasy kit and the TRIzol reagent (Invitrogen, Carlsbad, CA), and were shipped to this laboratory as dried

Table 2. Potato samples tested and viruses detected using enzyme-linked immunosorbent assay (ELISA) and macroarray hybridization analyses

\begin{tabular}{|c|c|}
\hline Potato accession $^{\text {a }}$ & Viruses detected $^{b}$ \\
\hline 257534 Valley & PVS, PVX \\
\hline All blue & CMV \\
\hline Altura 1 & PLRV, PVY \\
\hline Atlantic 1 & AMV \\
\hline Blossom & PVS, PVY \\
\hline Buffalo & PLRV, PVS, PVY \\
\hline Cinnabar & PLRV, PVY \\
\hline Colorado Long & PLRV, PVS, PVX, PVY \\
\hline Cosimar & PLRV, PVS \\
\hline Cups & PVY \\
\hline Dakchips & PLRV, PVS \\
\hline Elmer's Blue & PVS \\
\hline Eva 1 & PVS \\
\hline Eva 2 & AMV \\
\hline Eva 3 & TRV \\
\hline Grand Prairie & PVS, PVY \\
\hline Great Northern & PLRV, PVS, PVX \\
\hline Green Mountain 1 & PVA, PVS \\
\hline Green Mountain 2 & PVA, PVS \\
\hline Haig & PVS, PVX, PVY \\
\hline Hokkai & PVM \\
\hline ID-155 & PVY \\
\hline Inca Gold & PVS \\
\hline Jeremiah's Red & PLRV \\
\hline July & PLRV, PVS, PVX \\
\hline Mama Amarilla & PVS, PVY \\
\hline Mazama & PLRV, PVS \\
\hline ND2492-2R & PLRV, PVS \\
\hline NY139 & PVS \\
\hline Ostbote & PLRV \\
\hline Peach Blow & PLRV, PVS \\
\hline Pei Red & PVS \\
\hline Red Arcadian & PVS \\
\hline Red Banana & PVY \\
\hline Unknown $^{\mathrm{c}}$ & PVS, PVX \\
\hline W37-291A & PVM \\
\hline
\end{tabular}

a All potato accessions are Solanum tuberosum. The accession name usually contains or is the name of the potato sample as given at the time of receipt.

b The viruses specified are those detected using both ELISA and the macroarray. The acronyms are as follow: AMV, Alfalfa mosaic virus; CMV, Cucumber mosaic virus; PLRV, Potato leafroll virus; PVA, Potato virus A; PVM, Potato virus $M$; PVS, Potato virus $S$; PVX, Potato virus X; PVY, Potato virus $Y$; TRV, Tobacco rattle virus.

c The name of this potato cultivar is unknown. Although this tissue culture plant line was received as 'PLRV-Co', PLRV was not detected in any assay. 
ethanol precipitates at ambient temperature.

Reverse-transcription (RT) and amplification reactions with 1 to $4 \mu \mathrm{g}$ of total RNA were performed using an anchorlinked random primer as described (2). The PCR mix consisted of $2.5 \mu$ l of RT product, $0.2 \mu \mathrm{M}$ anchor-linked random primer P356 and $0.8 \mu \mathrm{M}$ anchor primer P357 (standard conditions), or $0.4 \mu \mathrm{M} \mathrm{P} 356$ and $0.4 \mu \mathrm{M}$ P357, $5 \mathrm{mM} \mathrm{MgCl} 2,10 \times$ ThermoPol buffer (New England Biolabs, Inc., Beverly, MA), $0.4 \mu \mathrm{M}$ dNTP mix, $2.5 \mathrm{U}$ of Taq polymerase (New England Biolabs, Inc.) and sterile distilled water to a total volume of $50 \mu \mathrm{l}$. The PCR was done at $94^{\circ} \mathrm{C}$ for $3 \mathrm{~min}$; followed by 35 cycles at $94^{\circ} \mathrm{C}$ for $30 \mathrm{~s}, 40^{\circ} \mathrm{C}$ for $30 \mathrm{~s}, 55^{\circ} \mathrm{C}$ for 1 min, and $72^{\circ} \mathrm{C}$ for $2 \mathrm{~min}$; a final extension at $72^{\circ} \mathrm{C}$ for $7 \mathrm{~min}$; and holding at $4^{\circ} \mathrm{C}$. The primer sequences were P356, 5'TGGTAGCTCTTGATCANNNNN-3' and P357, 5'-AGAGTTGGTAGCTCTTGATC$3^{\prime}$.

For the optimization of PCR conditions to favor the amplification of both viral and viroid cDNAs, equimolar PSTVd reverse and forward primers (P439 and P440, respectively) also were added to the PCR mix above at concentrations of $0,0.2,2$, and $20 \mathrm{nM}$. The primer sequences were P439, 5'-GGTTCCAAGGGCTAAACA CCCTCGC-3' and P440, 5'-CGGAAC TAAACTCGTGGTTCCTGTGG-3'; these were based on the GenBank accession no. EF580923. The primer pair P439/P440 amplify a near full-length, 344-bp cDNA copy of the PSTVd genome.

Probe design and printing on membranes. In all, 131 oligonucleotide probes were designed, ranging in size from 25 to 70 mers; the majority ( $84 \%$ ) of these were 70 mers. Complete genomic sequences of each of the viruses were retrieved from the National Center for Biotechnology Information database (http://www.ncbi.nlm.nih. gov/Genbank/index.html) and aligned using Vector NTI Suite 8 (InforMax, Inc., Frederick, MD). Generally, regions of sequence identity conserved among most or all strains of the virus were identified visually and used for the design of oligonucleotide probes. Wherever possible, probes were designed corresponding to different conserved regions of genomic RNAs; for multipartite genomes, where possible, probes were designed to target all RNAs. For the detection of TRV, a majority of the oligonucleotides were specific to RNA1, because RNA2 may not be present. In the case of viruses for which there was a high degree of variation among strains, even in the most conserved regions of the virus (e.g., for PVX), strains were grouped according to their similarities and oligonucleotides designed to the conserved regions for each group of strains. It should be noted that cross-hybridization to probes by targets from heterologous viruses was both expected and observed. Thus, the termi-
Table 3. Oligonucleotide probes used in the macroarray

\begin{tabular}{|c|c|c|c|c|}
\hline Probe $^{a}$ & Sequence $_{\text {accession }}{ }^{\mathrm{b}}$ & Nucleotide position $^{c}$ & Size $^{d}$ & Array coordinate \\
\hline PLRV-1 & AY138970 & $647-715$ & 69 & B3,4 \\
\hline PLRV-2 & AY138970 & $2,073-2,143$ & 70 & B5,6 \\
\hline PLRV-3 & AY138970 & $2,279-2,348$ & 70 & B7,8 \\
\hline PLRV-4 & AY138970 & $2,575-2,644$ & 70 & B9,10 \\
\hline PLRV-5 & AY138970 & $3,327-3,396$ & 70 & B11,12 \\
\hline PLRV-6 & AY138970 & $3,750-3,819$ & 70 & B13,14 \\
\hline PLRV-7 & AY138970 & $3,835-3,904$ & 70 & B15,16 \\
\hline PLRV-8 & AY138970 & $3,895-3,964$ & 70 & B17,18 \\
\hline PLRV-9 & AF453388 & $5,273-5,342$ & 70 & B19,20 \\
\hline PLRV-10 & AY138970 & $5,772-5,841$ & 70 & $\mathrm{~B} 21,22$ \\
\hline PLRV-11 & D13954 & $2,549-2,618$ & 70 & $\mathrm{~B} 23,24$ \\
\hline PLRV-12 & D13954 & $3,193-3,262$ & 70 & B25,26 \\
\hline PLRV-13 & AY138970 & $3,355-3,375$ & 25 & B27,28 \\
\hline PLRV-14 & AY138970 & $2,324-2,348$ & 25 & B29,30 \\
\hline PLRV-15 & AY138970 & $2,306-2,330$ & 25 & B31,32 \\
\hline PLRV-16 & AY138970 & $5,334-5,358$ & 25 & $\mathrm{C} 3,4$ \\
\hline PLRV-17 & AY138970 & $3,776-3,800$ & 25 & $\mathrm{C} 5,6$ \\
\hline PVA-1 & AJ131401 & $8,634-8,703$ & 70 & $\mathrm{C} 7,8$ \\
\hline PVA-2 & Z21670 & $9,235-9,304$ & 70 & C9,10 \\
\hline PVA-3 & AJ131403 & $9,460-9,529$ & 70 & $\mathrm{C} 11,12$ \\
\hline PVA-4 ${ }^{\mathrm{f}}$ & Z21670 & $2,895-2,964$ & 70 & $\mathrm{C} 13,14$ \\
\hline PVA- $5^{f}$ & Z21670 & $1,737-1,806$ & 70 & $\mathrm{C} 15,16$ \\
\hline PVA-6 & Z21670 & $1,514-1,583$ & 70 & $\mathrm{C} 17,18$ \\
\hline PVA-7 & Z21670 & $8,701-8,730$ & 30 & $\mathrm{C} 19,20$ \\
\hline PVA-8 & Z21670 & $1,476-1,507$ & 32 & $\mathrm{C} 21,22$ \\
\hline PVA-9 & Z21670 & $1,764-1,803$ & 40 & $\mathrm{C} 23,24$ \\
\hline PVA-10 & Z21670 & $8,058-8,127$ & 70 & $\mathrm{C} 25.26$ \\
\hline PVA-11 & Z21670 & $1,581-1,650$ & 70 & $\mathrm{C} 27,28$ \\
\hline PVA-12 & Z21670 & $5,251-5,320$ & 70 & $\mathrm{C} 29,30$ \\
\hline PVX-1 & M38480 & $6,254-6,323$ & 70 & C31,32 \\
\hline PVX-2 & AF373782 & $6,071-6,140$ & 70 & D3,4 \\
\hline PVX-3 & M38480 & $5,658-5,727$ & 70 & D5,6 \\
\hline PVX-4 & AY763582 & $167-236$ & 70 & D7,8 \\
\hline PVX-5 & AF172259 & $6,253-6,322$ & 70 & D9,10 \\
\hline PVX-6 & AF172259 & $4,261-4,330$ & 70 & D11,12 \\
\hline PVX-7 & X88786 & $568-637$ & 70 & D13,14 \\
\hline PVX- $8^{\mathrm{f}}$ & X72214 & $6,253-6,320$ & 70 & D15,16 \\
\hline$P V X-9^{f}$ & X72214 & $6,313-6,320$ & 70 & D17, 18 \\
\hline PVX-10 & X88785 & 395-464 & 70 & D19,20 \\
\hline PVX-11 & X88785 & $629-698$ & 70 & $\mathrm{D} 21,22$ \\
\hline PVX-12 & X88785 & $388-457$ & 70 & D23,24 \\
\hline PVY-1 & AJ890350 & $2-71$ & 70 & D25,26 \\
\hline PVY-2 & U09509 & $8,864-8,933$ & 70 & D27,28 \\
\hline PVY-3 & U09509 & $8,888-8,957$ & 70 & D29,30 \\
\hline PVY-4 & U09509 & $8,907-8,976$ & 70 & D31,32 \\
\hline PVY-5 & U09509 & $9,000-9,069$ & 70 & $\mathrm{E} 3,4$ \\
\hline \multicolumn{5}{|c|}{ (continued on next page) } \\
\hline
\end{tabular}

a PLRV, Potato leafroll virus; PVA, Potato virus A; PVX, Potato virus $X$; PVY, Potato virus $Y$; CMV, Cucumber mosaic virus; PotLV, Potato latent virus; PVS, Potato virus $S$; TRV, Tobacco rattle virus; PMTV, Potato mop-top virus; PSTV, Potato spindle tuber viroid; PVM, Potato virus M; AMV, Alfalfa mosaic virus.

${ }^{\mathrm{b}}$ Sequence accession refers to the GenBank accession number of the virus or host sequence used in the design of the oligonucleotide probe.

${ }^{c}$ Nucleotide position refers to the range of nucleotides in the respective sequence accession that are present in the oligonucleotide probe.

${ }^{\mathrm{d}}$ Size refers to the number of nucleotides in the respective oligonucleotide probe.

${ }^{\mathrm{e}}$ Array coordinate refers to the position of the of the oligonucleotide probe on the membrane. There are 12 columns, designated A to L, and 32 rows. The layout is that depicted in Figure 1.

${ }^{\mathrm{f}}$ Some probe sequences were consensus sequences and do not correspond exactly to any sequence accession. These probe sequences are as follows: PVA4, ACTTACTTGAGCCTTTTGGAG GATTCATGGCAAGAGTTAAGCTATTTTGGAAGATTTCAAGCAATAAGAC; PVA5, CCGGGA GGTGGATATAAGCAGTATATTGAGAGAAGAGTTCCAAATGGTGTCAGAAAACTTGCCATTG GAA; PVX8, GTGAAGATCACCAAGGCGAGGGCACAATCCAACGACTTTGCCAGTCTGGA TGCCGCGGTCACTAGGGGCC; PVX9, AGGCGAGGGCACAATCCAACGACTTTGCCAG TCTGGATGCCGCGGTCACTAGGGGCCGCATCACAGGAAC; PVS1, GCGGGTGGAGCTTGT GCTCAGATGGGATTTACAAAAAGCCGCAGCTGGTCTTTGAGAGACTTTGTATCGC; PVS11, ATAGGTCTTGTAGGGACTGGCTGGCCGACATGGGCATGGTCTTTTCAAAGTCTCAACTCT GCACCAAGTT; PVM6, GGACGAGATGCAGCTGTATCCACCTGGGTACTTTGACCTAGTTGT GAGTATGCTTAAAGTGGATGTGAGG; PVM14, AATGCGCTTCTCCGGGGAGGCAAGCACT TTTCTGTTTAACACGCTGGCCAATATGTTGTTCACCTTCATG; and PVM15, GCGCCCTACA TGCGGTACATTGAGATGAAAGTGCACGAGGTGCTGCCAAAGAATTACTACATCCACTCAG.

$\mathrm{g}$ The 'Plt rib 1' spotted on membranes was a composite mix of $5 \mu \mathrm{M}$ each of 18S rRNA2, 18S rRNA3, and $18 \mathrm{~S}$ rRNA4.

h The 'Plt rib 2' spotted on membranes was a composite mix of $5 \mu \mathrm{M}$ each of 25S rRNA5, 25S rRNA6, and $25 \mathrm{~S}$ rRNA7. 
Table 3. (continued from preceding page)

\begin{tabular}{|c|c|c|c|c|}
\hline Probe $^{a}$ & Sequence $_{\text {accession }}{ }^{b}$ & Nucleotide position $^{\mathrm{c}}$ & Size $^{d}$ & Array coordinate $e^{e}$ \\
\hline PVY-6 & U09509 & $9,029-9,098$ & 70 & E5,6 \\
\hline PVY-7 & U09509 & $9,055-9,124$ & 70 & $\mathrm{E} 7,8$ \\
\hline PVY-8 & U09509 & $9,255-9,324$ & 70 & E9,10 \\
\hline PVY-9 & U09509 & $9,301-9,370$ & 70 & E11,12 \\
\hline PVY-10 & U09509 & $9,377-9,446$ & 70 & E13,14 \\
\hline PVY-11 & U09509 & $9,409-9,478$ & 70 & E15,16 \\
\hline PVY-12 & U09509 & $9,629-9,698$ & 70 & $\mathrm{E} 17,18$ \\
\hline CMV-1 & AJ511988 & 88-187 & 70 & E19,20 \\
\hline CMV-2 & AJ511988 & $317-386$ & 70 & E21,22 \\
\hline CMV-3 & AJ511988 & $381-450$ & 70 & $\mathrm{E} 23,24$ \\
\hline CMV-4 & AJ517801 & $1,977-2,046$ & 70 & E25.26 \\
\hline CMV-5 & AJ517801 & $2,818-2,887$ & 70 & $\mathrm{E} 27,28$ \\
\hline CMV-6 & D10538 & $120-189$ & 70 & E29,30 \\
\hline CMV-7 & D10538 & $1,536-1,605$ & 70 & E31,32 \\
\hline CMV-8 & D10538 & $1,554-1,623$ & 70 & $\mathrm{~F} 3,4$ \\
\hline CMV-9 & AB189917 & $1,980-2,049$ & 70 & $\mathrm{~F} 5,6$ \\
\hline CMV-10 & AJ517802 & $2,002-2,071$ & 70 & $\mathrm{~F} 7,8$ \\
\hline CMV-11 & D10538 & 222-291 & 70 & $\mathrm{~F} 9,10$ \\
\hline CMV-12 & D10538 & $1,570-1,639$ & 70 & $\mathrm{~F} 11,12$ \\
\hline PotLV-1 & AY007728 & $152-221$ & 70 & $\mathrm{~F} 13,14$ \\
\hline PotLV-2 & AY007728 & $1,020-1,089$ & 70 & $\mathrm{~F} 15,16$ \\
\hline PotLV-3 & AY007728 & $1,288-1,357$ & 70 & $\mathrm{~F} 17,18$ \\
\hline PotLV-4 & AY007728 & $1,391-1,460$ & 70 & $\mathrm{~F} 19,20$ \\
\hline PotLV-5 & AY007728 & $742-811$ & 70 & $\mathrm{~F} 21,22$ \\
\hline PotLV-6 & AY007728 & $1,008-1,077$ & 70 & $\mathrm{~F} 23,24$ \\
\hline PVS- $1^{\mathrm{f}}$ & Y15625 & $804-873$ & 70 & $F 25,26$ \\
\hline PVS-2 & Y15623 & $421-490$ & 70 & $F 27,28$ \\
\hline PVS-3 $3^{\mathrm{f}}$ & Y15625 & $210-279$ & 70 & F29,30 \\
\hline PVS-4 & D00461 & $578-647$ & 70 & $\mathrm{~F} 31,32$ \\
\hline PVS-5 & D00461 & $286-355$ & 70 & G3,4 \\
\hline PVS-6 & Y15625 & $2,581-2,650$ & 70 & G5,6 \\
\hline PVS-7 & Y15613 & $1,002-1,071$ & 70 & $\mathrm{G} 7,8$ \\
\hline PVS-8 & Y15613 & 802-871 & 70 & G9,10 \\
\hline PVS-9 & Y15625 & $927-996$ & 70 & $\mathrm{G} 11,12$ \\
\hline PVS-10 & Y15625 & $507-576$ & 70 & G13,14 \\
\hline PVS $-11^{\mathrm{f}}$ & D00461 & $148-217$ & 70 & $\mathrm{G} 15,16$ \\
\hline PVS-12 & D00461 & $2,883-2,952$ & 70 & $\mathrm{G} 17,18$ \\
\hline PVS-13 & D00461 & $2,888-2,957$ & 70 & G19,20 \\
\hline TRV-1 & X06172 & $12-81$ & 70 & $\mathrm{G} 21,22$ \\
\hline TRV-2 & X06172 & $261-330$ & 70 & $\mathrm{G} 23,24$ \\
\hline TRV-3 & AF166084 & $972-1,041$ & 70 & G25.26 \\
\hline TRV-4 & X06172 & $1,101-1,170$ & 70 & $\mathrm{G} 27,28$ \\
\hline TRV-5 & X06172 & $1,446-1,515$ & 70 & G29,30 \\
\hline TRV-6 & X06172 & $2,420-2,489$ & 70 & $\mathrm{G} 31,32$ \\
\hline TRV-7 & X06172 & $3,803-3,872$ & 70 & $\mathrm{H} 3,4$ \\
\hline TRV-8 & X06172 & $5,160-5,229$ & 70 & $\mathrm{H} 5,6$ \\
\hline TRV-9 & X06172 & $5,775-5,844$ & 70 & $\mathrm{H} 7,8$ \\
\hline TRV-10 & X06172 & $5,921-5,990$ & 70 & $\mathrm{H} 9,10$ \\
\hline TRV-11 & X06172 & $6,194-6,263$ & 70 & H1 1,12 \\
\hline TRV-12 & X06172 & $6,719-6,788$ & 70 & $\mathrm{H} 13,14$ \\
\hline TRV-13 & AY166661 & $1-81$ & 70 & $\mathrm{H} 15,16$ \\
\hline TRV-14 & AY166661 & $3,605-3,674$ & 70 & $\mathrm{H} 17,18$ \\
\hline PMTV-1 & AJ238607 & $1,749-1,818$ & 70 & $\mathrm{H} 19,20$ \\
\hline PMTV-2 & AJ238607 & $2,610-2,679$ & 70 & $\mathrm{H} 21,22$ \\
\hline PMTV-3 & AJ238607 & $3,113-3,182$ & 70 & $\mathrm{H} 23,24$ \\
\hline PMTV-4 & AJ238607 & $3,442-3,511$ & 70 & H25.26 \\
\hline PMTV-5 & AJ238607 & $3,875-3,944$ & 70 & $\mathrm{H} 27,28$ \\
\hline PMTV-6 & AJ238607 & $4,226-4,295$ & 70 & $\mathrm{H} 29,30$ \\
\hline PMTV-7 & AY187010 & 293-362 & 70 & $\mathrm{H} 31,32$ \\
\hline PMTV-8 & AY187010 & $1,215-1,284$ & 70 & $\mathrm{I} 3,4$ \\
\hline PMTV-9 & AY187010 & $1,396-1,465$ & 70 & I5,6 \\
\hline PMTV-10 & D30753 & $2,369-2,438$ & 70 & $\mathrm{I} 7,8$ \\
\hline PMTV-11 & AJ243719 & 270-339 & 70 & I 9,10 \\
\hline PMTV-12 & AJ243719 & $1,976-2,045$ & 70 & I11,12 \\
\hline PMTV-13 & AF508256 & $53-122$ & 70 & I13,14 \\
\hline PMTV-14 & AF508256 & 244-313 & 70 & I15,16 \\
\hline PMTV-15 & AJ243719 & $2,692-2,791$ & 70 & $\mathrm{I} 17,18$ \\
\hline PSTV-1 & AY493560 & 203-272 & 70 & I19,20 \\
\hline PSTV-2 & AY493560 & $1-30$ & 30 & $\mathrm{I} 21,22$ \\
\hline PSTV-3 & AY493560 & 70-99 & 30 & $\mathrm{I} 23,24$ \\
\hline PSTV-4 & AY493560 & $319-348$ & 30 & I25.26 \\
\hline PSTV-5 & AY493560 & $252-282$ & 31 & $\mathrm{I} 27,28$ \\
\hline PSTV-6 & AY493560 & $10-38$ & 29 & $\mathrm{I} 29,30$ \\
\hline \multicolumn{5}{|c|}{ (continued on next page) } \\
\hline
\end{tabular}

nology 'virus-specific' indicates that probe synthesis was based on a specific virus sequence, not that hybridization will necessarily be specific. As positive or reference controls, six 70-mer probes corresponding to conserved plant ribosomal RNAs were designed, three for the 18S rRNA and three for the 25S RNA (Table 3).

The virus specificity of each of these oligonucleotides was evaluated using BLAST, the Basic Local Alignment Search Tool (3). The Oligo Analyzer 3.0 tools (Integrated DNA Technologies, Coralville, IA) were used for analysis of $\mathrm{G}+\mathrm{C}$ content and melting temperature $\left(\mathrm{T}_{\mathrm{m}}\right)$, and to predict hairpin formation and self-annealing properties of each oligonucleotide. Those oligonucleotides selected exhibited $\mathrm{T}_{\mathrm{m}}$ of about $70^{\circ} \mathrm{C}$, a relatively lower tendency to form homo dimers, and the least stable hairpin structures. Oligonucleotides were synthesized commercially (Integrated DNA Technologies), and the viral, viroid, and ribosomal RNA-specific oligonucleotides are listed in Table 3.

Printing of oligonucleotide probes on membranes. Ribosomal and virus- or viroid-specific DNA oligonucleotide probes were diluted to final concentrations of 10 and $20 \mu \mathrm{M}$, respectively, in $1 \times$ spotting buffer $(4 \mu \mathrm{M}$ sodium carbonate buffer, $\mathrm{pH} 8.0 ; 3 \times \mathrm{SSC}[1 \mathrm{SSC}$ is $0.15 \mathrm{M} \mathrm{NaCl}$ and $0.15 \mathrm{M}$ sodium citrate]; $0.01 \% \mathrm{~N}$ lauroylsarcosine; and $0.004 \%$ bromophenol blue). The probes were transferred in $30-\mu l$ aliquots into the wells of a polypropylene 384-well microtiter plate (Nalge Nunc International, Rochester, NY). A pin replicator (VP 386; V\&P Scientific, Inc., San Diego, CA) for 384-well plates was cleansed as recommended by its manufacturer prior to printing. Hybond-N Plus membranes (GE Healthcare Bio-Sciences Corp., Piscataway, NJ) were cut to the size (12 by $10 \mathrm{~cm}$ ) of a multiprint device (VP 381; V\&P Scientific) and the copier unit (VP 382; V\&P Scientific) aligned over the 384-well plate. The oligonucleotides were printed on a membrane on the same spots twice. The pin replicator delivered approximately $0.1 \mu \mathrm{l}$ per print. Five minutes was allowed for air drying the membrane before the second printing. The printed oligonucleotides were fixed onto the membrane by UV-cross-linking for $2 \mathrm{~min}$ at 120 $\mathrm{mJ} / \mathrm{s}$ in a Stratalinker (Strategene Corp., La Jolla, CA).

The oligonucleotides were printed on membranes in the pattern depicted in Figure 1 , with virus-specific oligonucleotides organized in groups. The exact row and column coordinates for the placement of each oligonucleotide are specified in Table 3. Two plant ribosomal RNA-specific oligonucleotide mixtures were prepared, 'Plt rib 1' and 'Plt rib 2'. Plt rib1 consisted of 5 $\mu \mathrm{M}$ each of $18 \mathrm{~S}$ rRNA2, 18S rRNA3, and $18 \mathrm{~S}$ rRNA4. Plt rib 2 consisted of $5 \mu \mathrm{M}$ each of 25S rRNA5, 25S rRNA6, and 25S rRNA7 (Table 3). 
Table 3. (continued from preceding page)

\begin{tabular}{|c|c|c|c|c|}
\hline Probe $^{a}$ & Sequence accession $^{b}$ & Nucleotide position $^{c}$ & Size $^{d}$ & Array coordinate $\mathrm{e}^{\mathrm{e}}$ \\
\hline PSTV-7 & AY493560 & $206-252$ & 48 & $\mathrm{I} 31,32$ \\
\hline PSTV-8 & AY492083 & $267-316$ & 51 & $\mathrm{~J} 3,4$ \\
\hline PSTV-9 & AY492083 & $107-136$ & 30 & $\mathrm{~J} 5,6$ \\
\hline PSTV-10 & AY492083 & $64-133$ & 70 & $\mathrm{~J} 7,8$ \\
\hline PSTV-11 & AY4920832 & $101-150$ & 50 & $\mathrm{~J} 9,10$ \\
\hline PSTV-12 & AY492083 & 113-142 & 30 & $\mathrm{~J} 11,12$ \\
\hline PVM-1 & AF023877 & $1,117-1,186$ & 70 & $\mathrm{~J} 13,14$ \\
\hline PVM-2 & AF023877 & $2,277-2,346$ & 70 & $\mathrm{~J} 15,16$ \\
\hline PVM-3 & AF023877 & $1,539-1,608$ & 70 & $\mathrm{~J} 17,18$ \\
\hline PVM-4 & AY311394 & $6,491-6,560$ & 70 & $\mathrm{~J} 19,20$ \\
\hline PVM-5 & AJ437481 & $8,323-8,392$ & 70 & $\mathrm{~J} 21,22$ \\
\hline PVM-6 ${ }^{\mathrm{f}}$ & AJ437481 & $3,805-3,874$ & 70 & $\mathrm{~J} 23,24$ \\
\hline PVM-7 & AY311395 & $631-700$ & 70 & $\mathrm{~J} 25.26$ \\
\hline PVM-8 & AJ437481 & $4,586-4,655$ & 70 & $\mathbf{J} 27,28$ \\
\hline PVM-9 & AJ437481 & $1,139-1,208$ & 70 & $\mathbf{J} 29,30$ \\
\hline PVM-10 & AJ437481 & $7,593-7,662$ & 70 & $\mathrm{~J} 31,32$ \\
\hline PVM-11 & D14449 & $5,715-5,784$ & 70 & $\mathrm{~K} 3,4$ \\
\hline PVM-12 & D14449 & $5,325-5,394$ & 70 & $\mathrm{~K} 5,6$ \\
\hline PVM-13 & D14449 & $5,112-5,181$ & 70 & $\mathrm{~K} 7,8$ \\
\hline PVM-14 & D14440 & $5,487-5,556$ & 70 & K9, 10 \\
\hline PVM- $15^{\mathrm{f}}$ & D14440 & $5,200-5,269$ & 70 & $\mathrm{~K} 11,12$ \\
\hline AMV-1 & AB126032 & $1,748-1,817$ & 70 & $\mathrm{~K} 13,14$ \\
\hline AMV-2 & AB126032 & $1,749-1,782$ & 34 & $\mathrm{~K} 15,16$ \\
\hline AMV-3 & AB126031 & $1,354-1,388$ & 35 & $\mathrm{~K} 17,18$ \\
\hline AMV-4 & AB126032 & $1,288-1,313$ & 26 & $\mathrm{~K} 19,20$ \\
\hline AMV-5 & K03542 & $368-437$ & 70 & $\mathrm{~K} 21,22$ \\
\hline AMV-6 & K03542 & $463-532$ & 70 & $\mathrm{~K} 23,24$ \\
\hline AMV-7 & K03542 & $603-672$ & 70 & $\mathrm{~K} 25.26$ \\
\hline AMV-8 & K03542 & $700-769$ & 70 & $\mathrm{~K} 27,28$ \\
\hline AMV-9 & K03542 & 802-871 & 70 & $\mathrm{~K} 29,30$ \\
\hline AMV-10 & K03542 & $1,193-1,262$ & 70 & $\mathrm{~K} 31,32$ \\
\hline AMV-11 & AB 126032 & $1,193-1,262$ & 70 & $\mathrm{~L} 3,4$ \\
\hline AMV-12 & K03542 & $1,714-1,783$ & 70 & $\mathrm{~L} 5,6$ \\
\hline $18 \mathrm{~S}$ rRNA2 ${ }^{\mathrm{g}}$ & U42796 & 857-926 & 70 & A 1 to $\mathrm{L} 1, \mathrm{~A} 2$ to $\mathrm{L} 2$ \\
\hline 18S rRNA3g & U42796 & $1,242-1,311$ & 70 & $\mathrm{~A} 1$ to $\mathrm{L} 1, \mathrm{~A} 2$ to $\mathrm{L} 2$ \\
\hline 18S rRNA4" & U42796 & $1,586-1,655$ & 70 & A1 to $\mathrm{L} 1, \mathrm{~A} 2$ to $\mathrm{L} 2$ \\
\hline $25 \mathrm{~S}$ rRNA5 ${ }^{\mathrm{h}}$ & M11585 & $858-927$ & 70 & A 3 to $\mathrm{A} 32$ \\
\hline $25 \mathrm{~S}$ rRNA6 ${ }^{\mathrm{h}}$ & M11585 & $2,287-2,356$ & 70 & A 3 to $\mathrm{A} 32$ \\
\hline $25 \mathrm{~S}$ rRNA $7^{\mathrm{h}}$ & M11585 & $1,230-1,299$ & 70 & A 3 to A32 \\
\hline
\end{tabular}

Purification of PCR products, chemical labeling, hybridization, and detection. The randomly primed amplification products were analyzed by gel electrophoresis, purified, quantified, and chemically labeled as described by Agindotan and Perry (2). The chemical labeling of the purified PCR product was done using an AlkPhos Direct labeling kit (GE Healthcare Bio-Sciences Corp.) following the manufacturer's protocol, except that 200 ng of DNA was labeled with $1 \mu \mathrm{l}$ of the alkaline phosphatase reagent. Prehybridization and hybridization were done at $55^{\circ} \mathrm{C}$ using the hybridization protocol provided with the Alkphos Direct kit. The membranes were incubated with CDP-star chemiluminescent reagent (GE Healthcare Bio-Sciences Corp.) for $5 \mathrm{~min}$, drained, and exposed to Chemiluminescence Bio Max film (Kodak Co., Rochester, NY) for $2 \mathrm{~h}$ to overnight.

\section{RESULTS}

Design of the macroarray. Oligonucleotides were designed to hybridize to either plant rDNA sequences or to viral cDNAs. The rDNA-specific oligonucleotides were spotted along the left side and top of the membrane in order to highlight and provide orientation for the rows and columns, respectively. To facilitate a visual reading of results, oligonucleotides designed to detect a given virus were spotted together in succession (blocks) following a pattern of top to bottom and left to right. Additionally, each oligonucleotide was spotted in duplicate as an adjacent pair. The array pattern is illustrated schematically as a table (Fig. 1A) and in the results from a hybridization experiment using amplified and labeled target cDNAs derived from RNAs extracted from an uninfected plant (Fig. 1B). The row and column coordinates for the placement and identity of each oligonucleotide are specified in Table 3. In the experiment depicted in Figure 1B, target cDNAs hybridized to two of the 'virus-specific' oligonucleotides, PVX-4 and PVX-6. This same crosshybridization of host cDNAs with PVX-4 and PVX-6 was observed in other experiments and, in most experiments with virusinfected plants, hybridization with PVX-6 was observed (Figs. 2 and 3).

For most viruses, 12 virus-specific probes were designed and spotted on the membrane. In the case of the carlaviruses (e.g., PotLV, PVM, and PVS), oligonucleotides were selected from regions of the genome most conserved among all members and, as a result, some cross- hybridization might be expected. There was sequence information for only one isolate of PotLV and only six oligonucleotides were designed and spotted. For PVM, there was significant sequence variability among genomes, and 15 oligonucleotides were designed and spotted in order to be able to detect all sequenced isolates.

Testing of the macroarray using reference standards of plant viruses. In order to validate the macroarray, stocks of virus-infected plants routinely used as positive controls in ELISA analyses were employed. Most virus stocks were maintained as in-vitro-grown plants, some for decades; alternatively, greenhouse-grown plants were employed. A majority of these infected plants originated as field isolates and some are mixed infections with PVS or PVX in addition to the virus of interest (Table 1). Macroarray results using these virus stocks are shown in Figure 2 and, in each case where a virus was detected, the spot positions for all of the oligonucleotides designed to be specific to that virus are collectively boxed. The vast majority of the spotted oligonucleotides are 70 mers although, in some cases, shorter 25 to 51 mers were designed (Table 3 ).

All of the virus reference standards were detected using the macroarray and, in all experiments, we observed a consistency in results from DAS-ELISA and macroarray assays (Fig. 2). In most cases, at least 12 oligonucleotides probes were designed and employed, though rarely did they all prove effective. In the detection of AMV, 9 of the 12 probes hybridized with labeled nucleic acids amplified from infected plants, although the hybridization signals for only five probes were strong and easily visible (Fig. 2A). By contrast, 11 of 12 and 12 of 13 oligonucleotides specific for PVA and PVS, respectively, were effective in detecting virus in infected plants (Fig. 2E, $\mathrm{H}$, and elsewhere). PVS is a member of the genus Carlavirus and the high proportion of effective oligonucleotides is a reflection, in part, of the high degree of sequence identity among isolates. For the related PotLV, there was limited sequence information available (one isolate); however, the strategy of selecting regions of the genome most conserved among PotLV and other carlaviruses proved successful in that all six PotLV probes hybridized with the labeled target from infected plants (Fig. 2D). The situation with the related PVM proved much different in that there were multiple isolates and sequences, some of which shared more limited sequence identity (8). Fifteen PVM probes were designed and labeled targets from plants infected with reference isolates hybridized with either 6 or 11 of the probes (Fig. 2F and $\mathrm{G})$. Because probe design for all these carlaviruses focused on regions conserved among species, it was not surprising to observe cross-hybridization. Amplified cDNAs from isolate PVM-Idaho hybrid- 


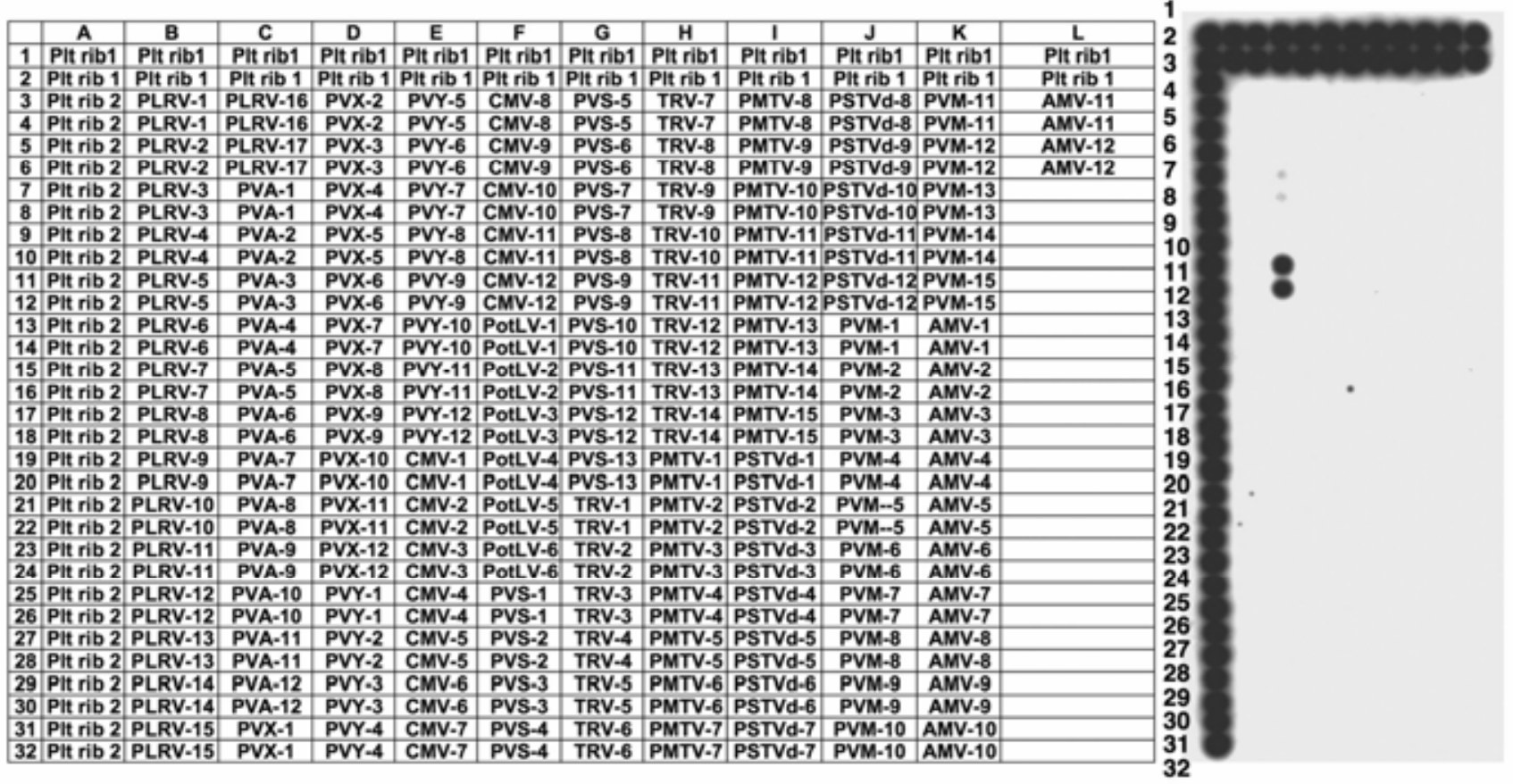

Fig. 1. Macroarray layout of spotted oligonucleotides on the nylon membrane. A, Placement of oligonucleotides in the macroarray is shown on a 12-column and 32-row grid (columns A to L, rows 1 to 32). In each cell, the name of a spotted oligonucleotide is indicated. In rows 1 and 2 and column A, the 'Plt rib1' and 'Plt rib2' refer to a mixtures of oligonucleotides complementary to plant ribosomal RNA gene sequences. B, Film showing results from an experiment wherein labeled complementary DNAs were amplified from RNA extracts prepared from an uninfected plant. The signals at the top of each column and the left side of each row define the grid pattern shown in panel A, and correspond to the hybridization of complementary DNAs to the rRNA-specific probes. A strong signal is observed corresponding to the hybridization of plant cDNAs to probe Potato virus $X$ (PVX)-6 and a weak signal corresponding to hybridization to probe PVX-4.

ized with probes PVS-2 and -4, although this was not observed with cDNAs from PVM-Hokkai (Fig. 2F and G). Similarly, some PVS isolate cDNAs cross-hybridized with probes PVM-8 and -14 (Fig. $2 \mathrm{H}$ ), and PotLV cDNAs strongly cross-hybridized with PVS-1, PVS-4, PVS-6, and PVM-14 (Fig. 2D). Additional cross-hybridization also can be observed among carlaviruses (Figs. 2 and 3).

Among the viruses in the genera Potexvirus and Tobravirus, the common potato virus PVX generally accumulates to high titers. Hybridization signals from experiments with extracts of plants infected with PVX were usually very strong, with those shown in Figure 2I more typical than those in Figure 2K. The Tobravirus TRV is less predictable in its accumulation; however, probes for this virus proved to be quite effective for the three isolates tested (Fig. $2 \mathrm{~K}$; data not shown). Results from experiments to detect three remaining viruses in this study, CMV, PLRV, and PVY, were consistent with those described in a previous report using the same oligonucleotides probes (2) (Fig. 2B, C, and J).

Analysis of potato field isolates infected with multiple viruses. In order to further evaluate the use of the macroarray, a collection of virus field isolates was tested to compare the results of conventional serological assays with those obtained with the macroarray assay. Thirtysix potato accessions derived from virus- infected field collections are maintained in vitro in the Cornell University collection. These accessions were analyzed and the viruses detected by both macroarray and serological assays are shown in Table 2. Again, there was complete agreement between results obtained from the ELISA and macroarray testing. Results from a subset of the macroarray assays performed are shown in Figure 3, with an emphasis on accessions harboring multiple viruses. Of the 36 accessions, 4 harbored three viruses and 1 supported replication of four viruses. Clear detection was observed for all viruses with various combinations of PLRV, PVS, PVX, and PVY; the most impressive accession was Colorado Long, which harbored all four viruses (Fig. 3B). The dual presence of viruses did not appear to interfere with detection although, in some cases, such as for PVY in the accession Haig and PLRV in July, hybridization signals were weak (Fig. 3C and D). But even in these examples, the weak hybridization signal for 11 and 7 probes, respectively, made the assessment of an infecting virus unambiguous and results were consistent with those from ELISA. Furthermore, weak hybridizations have been observed in cases of plants infected with single viruses (results not shown); presumably, these were from plants with a low concentration of virus. These data, along with those shown in Figure 2, suggest there will be no major impediment to the detection of multiple viruses when present in a single plant.

Macroarray detection of PMTV. Probes on the macroarray were included for the detection of PMTV. Although this is an emerging pathogen in North America $(19,37)$, no domestic isolates have been available for testing. Therefore, RNA extracts from infected plants were requested from Europe in order to gain a preliminary indication of probe efficacy. Two samples of PMTV were obtained, the isolate Oleva from an infected $N$. benthamiana plant and a second sample from the tuber of infected potato cv. Van Gogh. Both source plants had been shown to be ELISA positive for the presence of PMTV (J. Valkonen and J. Aura, personnel communication). The dried RNA extracts were processed to generate labeled targets and the macroarray results are shown in Figure 4. Complementary DNAs derived from the infected $N$. benthamiana hybridized with all 15 of the oligonucleotide probes, although hybridization to some probes was relatively weak (Fig. 4A). Using RNA extracts from infected tubers, a relatively weak hybridization was observed with only 5 of the 15 probes (Fig. 4B). Testing for TRV in tubers can be difficult due to low concentrations and the uneven distribution of the virus in tubers, and the latter result is consistent with a lower titer or recovery of viral RNAs from infected tubers. Additionally, we have no sequence information 
A

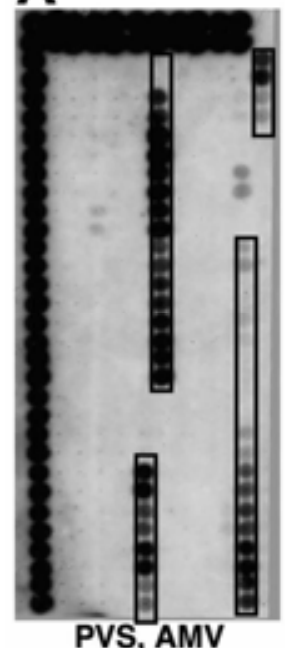

E

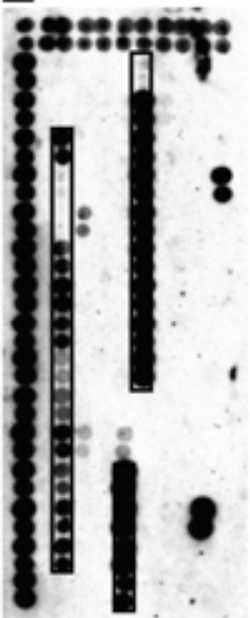

PVA, PVS

I

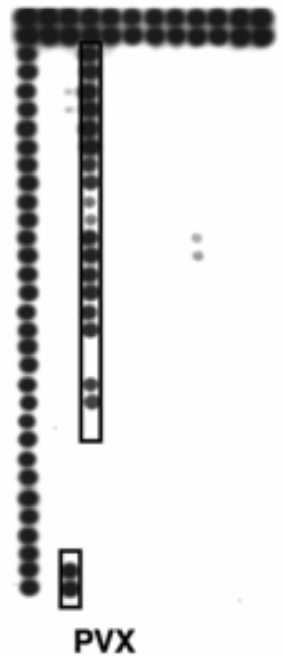

B

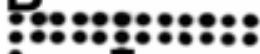

:

:

$: 0$
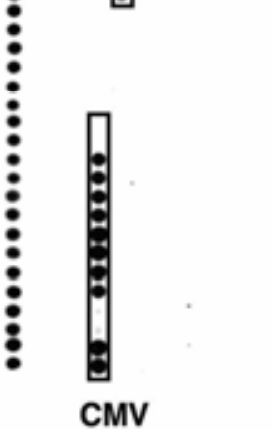

F

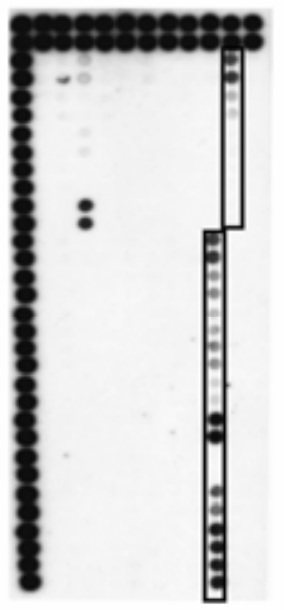

PVM-Hokkai

J

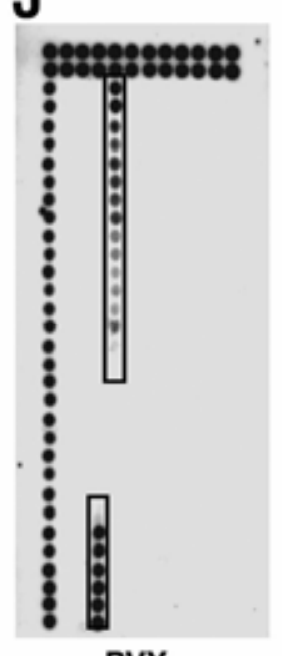

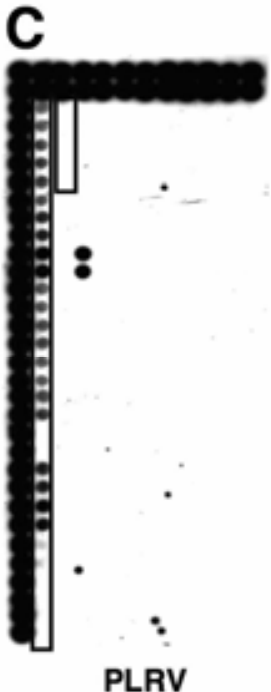

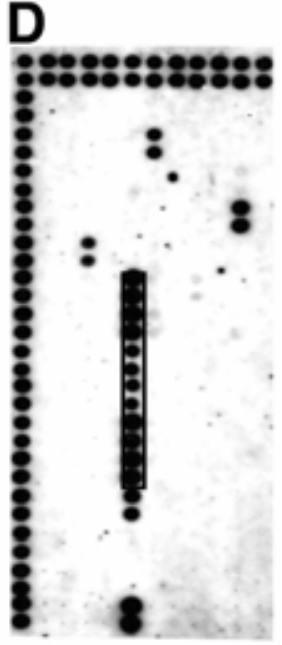

PotLV

G

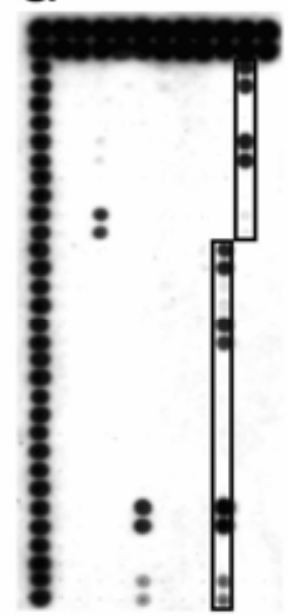

H

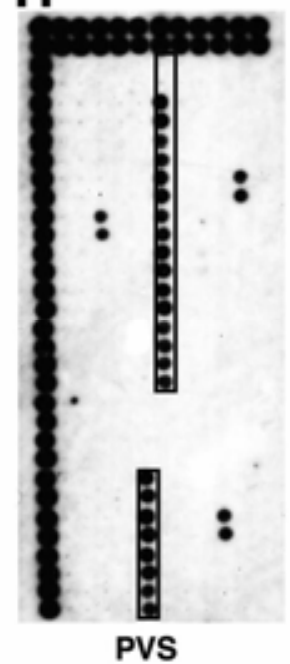

PVM-Idaho

K

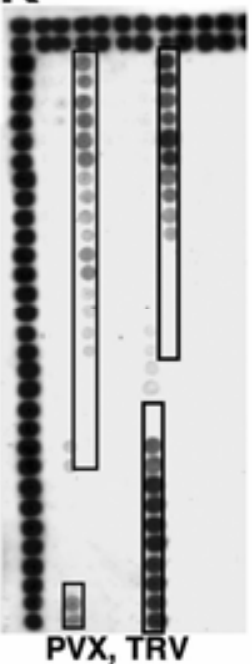

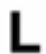

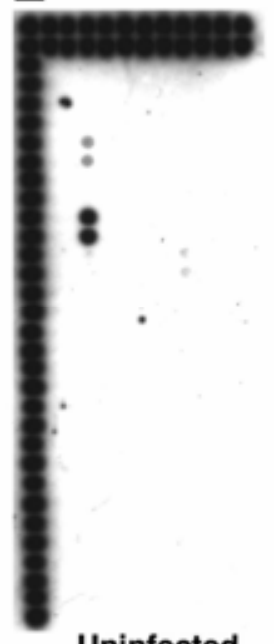

Fig. 2. Macroarray detection of reference isolates of potato-infecting viruses. A-L, Films exposed to hybridized macroarrays for 1 to $3 \mathrm{~h}$, showing the hybridization of polymerase chain reaction-amplified and labeled complementary DNA targets. The RNAs used to prepare the amplified targets were derived from virus-infected Solanum tuberosum plants. The acronyms of the infecting viruses (isolate name) are indicated below each panel: A, Potato virus $S$ (PVS) and Alfalfa mosaic virus (AMV); B, Cucumber mosaic virus (CMV); C, Potato leaf roll virus (PLRV); D, Potato latent virus (PotLV); E, Potato virus A (PVA) and PVS; F, Potato virus M (PVM)-Hokkai isolate; G, PVM-Idaho isolate; H, PVS; I, Potato virus X (PVX); J, Potato virus Y (PVY); K, PVX and Tobacco rattle virus (TRV); and $\mathbf{L}$, uninfected potato. 
on PMTV isolates Oleva and Van Gogh. Although no additional isolates were tested, these initial results show that all of the probes have the ability to hybridize with cDNAs prepared from PMTVinfected plants.

Macroarray detection of PSTVd. Twelve oligonucleotides were included in the array for the detection of PSTVd. In initial experiments employing the standard RT-PCR amplification procedure, a consistent and unambiguous detection of PSTVd was not achieved although, depending on the experiment, faint hybridization was observed with probes PSTVd-4, -7, -8, -10, and -11 (Fig. 5A and D). By contrast, PSTVd could be detected easily if, at the PCR step, a relatively small quantity of the PSTVd-specific primer pair P439/P440 was included in the reaction (Fig. 5C, E, and $\mathrm{F}$ ). This primer pair amplifies a nearly full-length PSTVd genome, 344 of 357 nucleotides. PSTVd amplification and its detection on the macroarray was effective using a molar ratio of only 1:40 for the PSTVd-specific primers P439/P440 (20 $\mathrm{nM}$ each) versus the anchor primer P357 $(800 \mathrm{nM})$; reducing this ratio 10 -fold to 1:400 or lower did not allow for PSTVd detection in some experiments (Fig 5B; data not shown). It was not necessary to include the PSTVd-specific primer P439 at the RT step, so long as the PSTVd-specific primer pair was included in the amplification reaction (compare Fig. 5E and F). Four isolates of PSTVd (Table 1) were easily detected in seven infected plant backgrounds. Five of these seven PSTVdinfected potato isolates also were infected by PVS and both pathogens were distinguished in the macroarrays (Fig. 5C, E, and F; data not shown). As described above, hybridization to additional probes for other viruses are seen in Figure 5 (e.g., probes PVX-6, PMTV-13, PVM-8, and PVM-14), but these did not confuse the interpretation of results (see Discussion). In order to test for the detection of PSTVd in the presence of an additional virus, a potato line with PSTVd-UF2, PVS, and PVX was employed; all three pathogens were clearly observed in the macroarray (Fig. 5E and F). Thus, modifying the amplification reaction to include a relatively small amount of a specific primer pair is compatible with the random primed amplification of viral
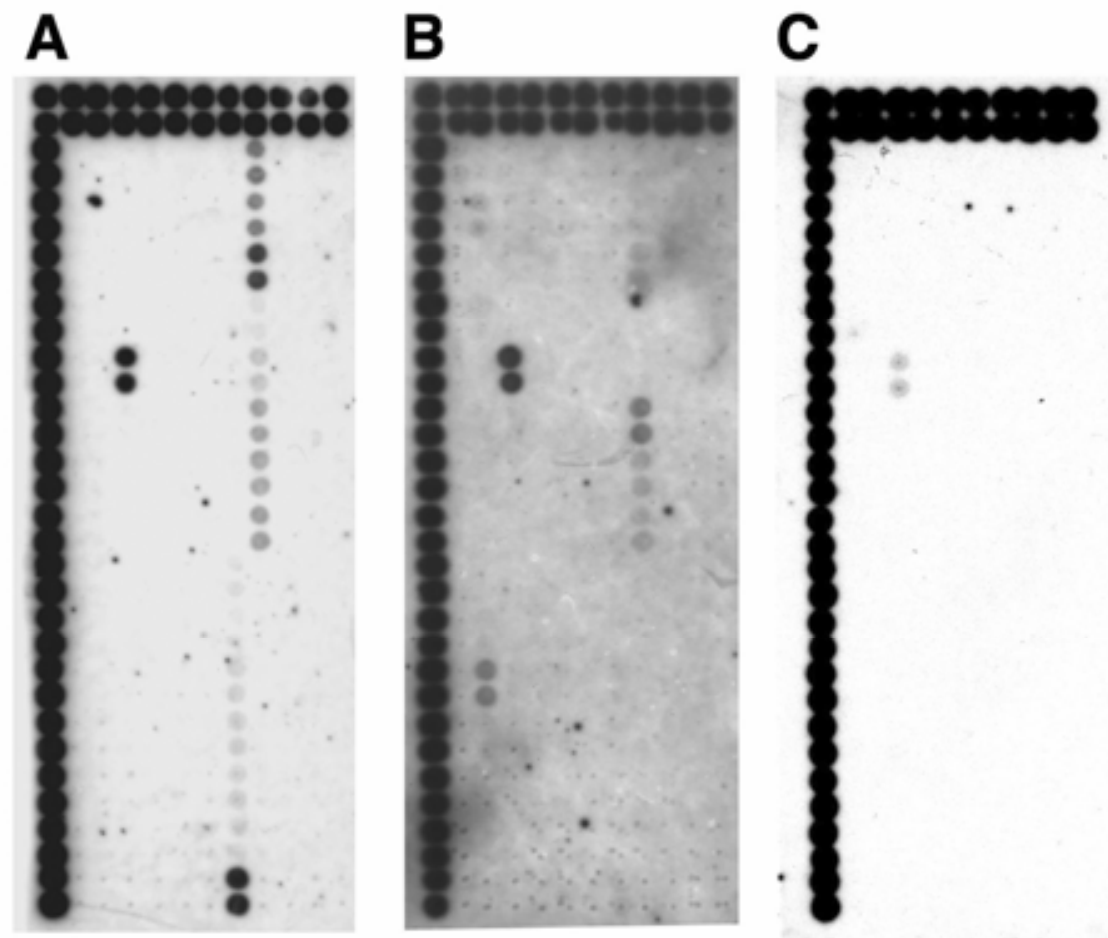

Fig. 4. Macroarray detection of Potato mop top virus (PMTV). RNAs used to prepare target cDNAs were extracted from A, leaves of PMTV-infected Nicotiana benthamiana; B, tubers of PMTV-infected potato $\mathrm{cv}$. Van Gogh; and $\mathbf{C}$, leaves of uninfected $N$. benthamiana. The RNA samples in A and B were received as dried pellets, whereas that in $\mathrm{C}$ was from a fresh leaf sample.

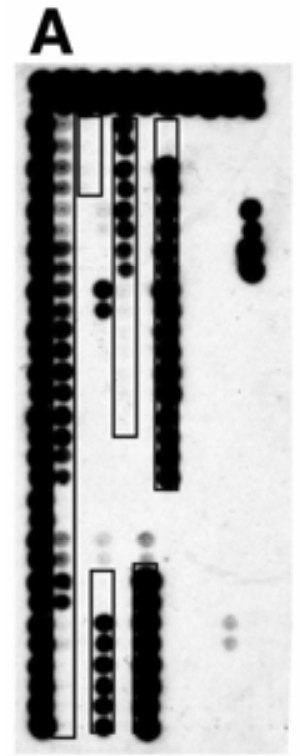

Buffalo
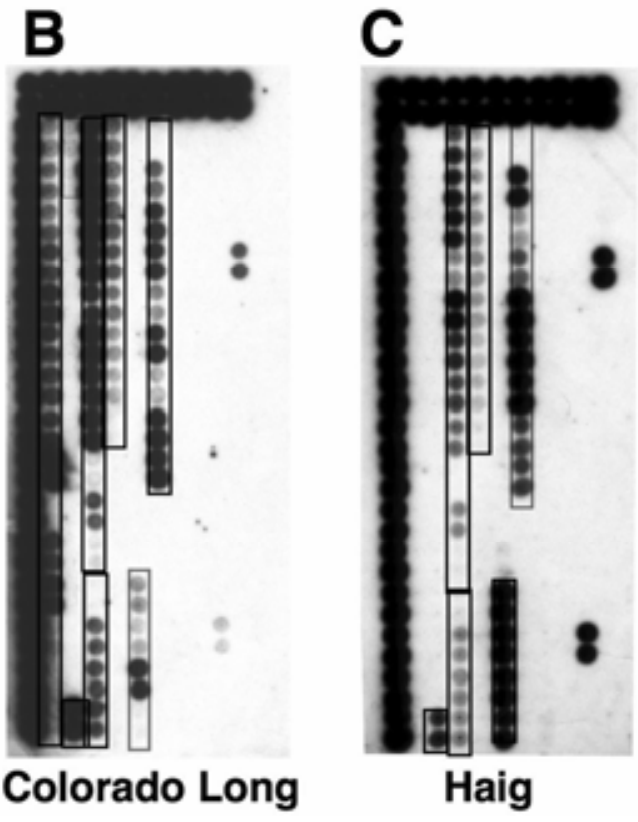

Haig

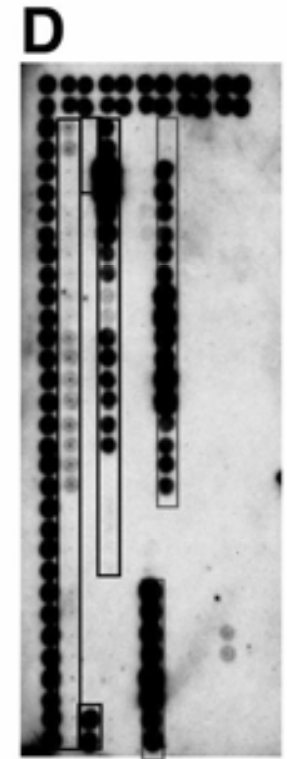

July

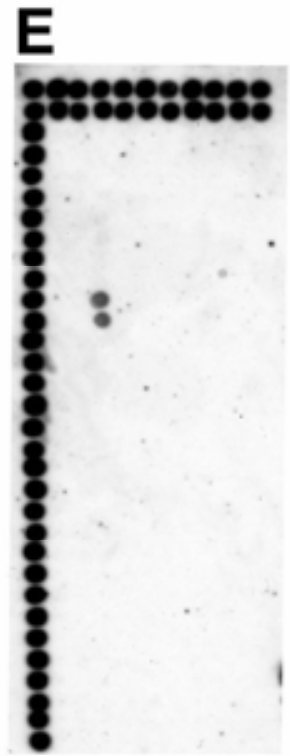

Uninfected Eva

Fig. 3. Macroarray detection of mixed infections of multiple potato-infecting viruses in single plants. A-E, Films showing the hybridization of polymerase chain reaction-amplified and labeled complementary DNA targets. The RNAs used to prepare the amplified targets were derived from virus-infected Solanum tuberosum plants. The name of the potato cultivars sampled are indicated below each panel: A, Buffalo; B, Colorado Long; C, Haig; D, July; and E, an uninfected Eva. 


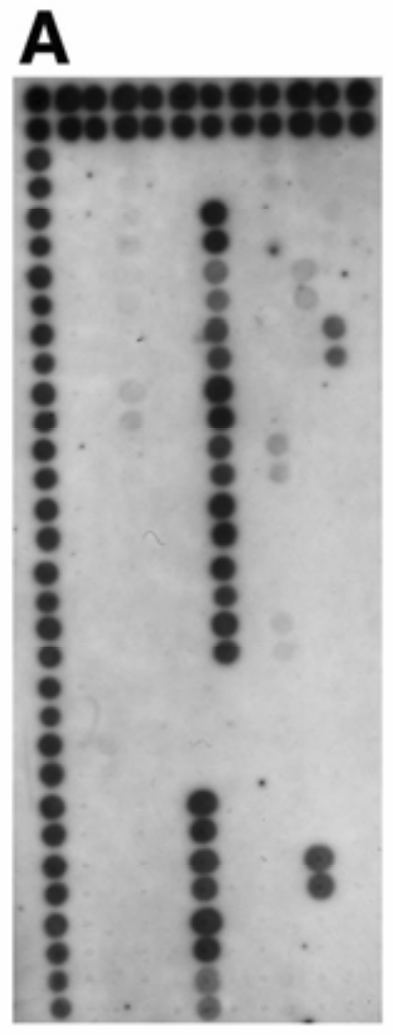

B

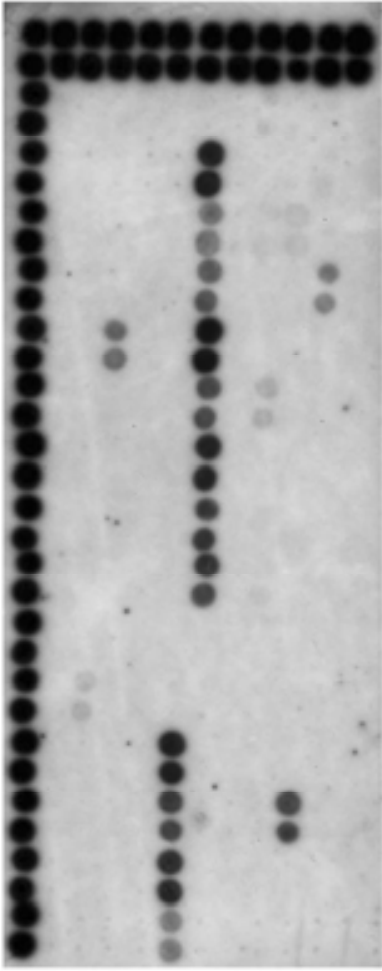

E

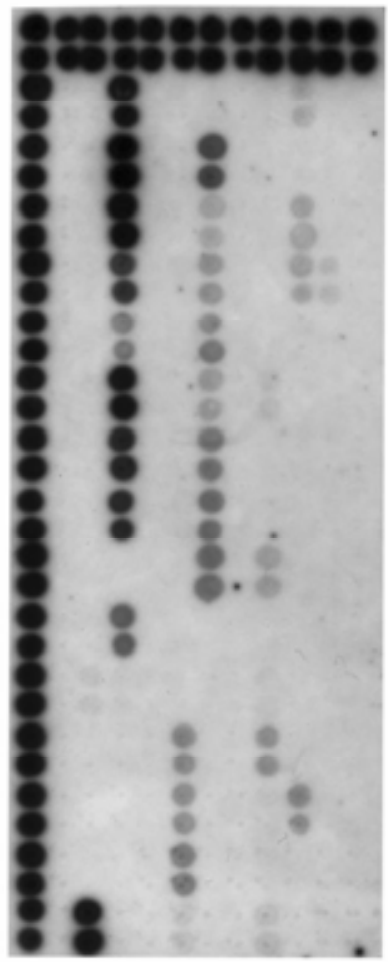

C

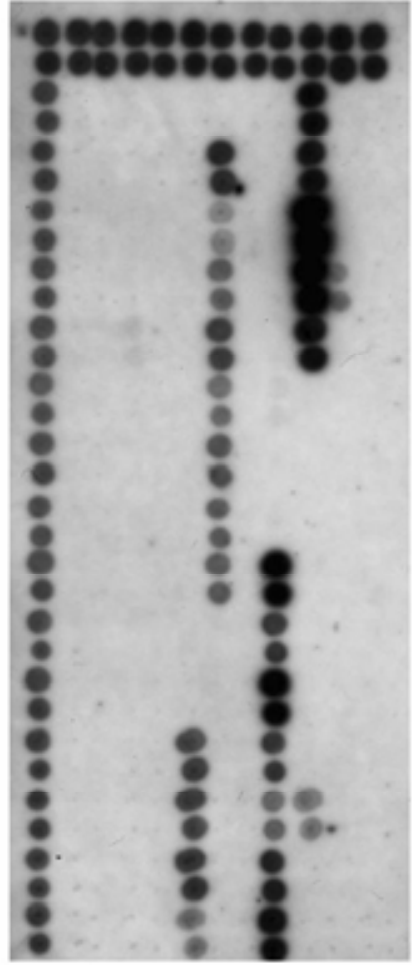

$\mathbf{F}$

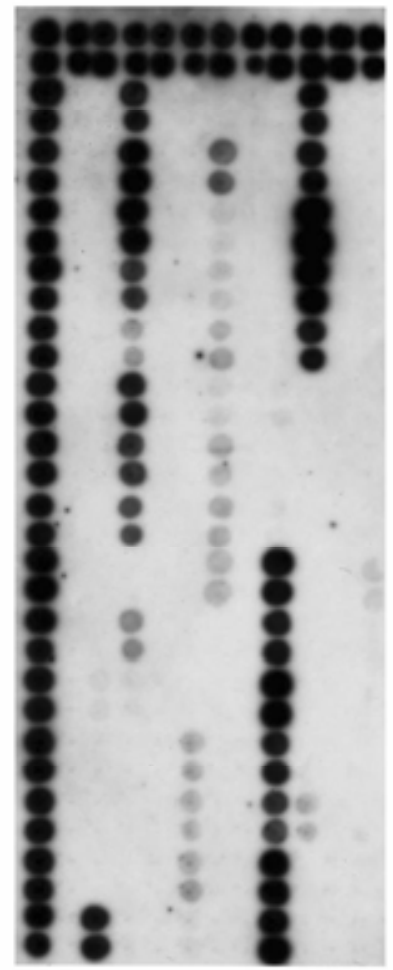

Fig. 5. Optimization of Potato spindle tuber viroid (PSTVd) amplification and detection by macroarray. A-C, Macroarrays hybridized with complementary DNAs prepared from potato infected with PSTVd isolate 1989 and Potato virus $S$ (PVS). These target DNAs were transcribed and amplified by reversetranscription polymerase chain reaction (RT-PCR) using the anchored random primer P357 (standard RT-PCR conditions) with the addition of PSTVdspecific primers P439 and P440 at concentrations of A, 0.0; B, 2.0; and C, $20 \mathrm{~nm}$. D-F, Macroarrays hybridized with complementary DNAs prepared from potato infected with PSTVd isolate UF2, PVS, and Potato virus X (PVX). Target DNAs were amplified using standard RT-PCR conditions with either D, no modifications; E, PSTVd-specific primers P439 and P440 at $20 \mathrm{~nm}$ added to the PCR reaction; or F, PSTVd-specific primer P439 added to the RT reaction (to $50 \mathrm{nM}$ ) and PSTVd-specific primers P439 and P440 at $20 \mathrm{~nm}$ added to the PCR reaction. 
sequences and the detection of multiple pathogens.

\section{DISCUSSION}

North American foundation potato seed programs most commonly screen for six viruses using serological techniques (ELISA; 29). In this study, all six viruses (PVA, PVM, PVS, PVX, PVY, and PLRV) were clearly detected in the macroarray. Our observations in this work were that the sensitivity appeared to be comparable with that of ELISA, although we made no quantitative comparisons as were done previously (2). Recent work on PotLV (5) and TRV (10), and the emergence of PMTV in North America $(19,37)$, has led to an interest in monitoring for these viruses. Sources of polyclonal antisera to PotLV and PMTV are limiting and, in the case of TRV, antisera will not reliably detect all infections due to the occasional loss of a coat protein encoding RNA (15). For TRV, the macroarray circumvents these issues and allows for the detection of all the viruses of particular interest in North America. Although an analysis of multiple isolates of PMTV is hindered by their availability and quarantine restrictions, results were encouraging in that 12 of the 13 probes hybridized with the target prepared from what appears to be a single isolate of this virus (Fig. 4). The latter results were obtained using target prepared from RNAs from the experimental host $N$. benthamiana, not from potato. Our results using an RNA extract from a PMTV-infected potato tuber did not give as strong a signal (Fig. 4B) as observed in experiments with leaf tissue from most other virus-infected potato; this may be due to lower virus titers or an uneven distribution of the virus in tubers. The macroarray detection of PMTV may prove challenging because it has been using serological techniques (14), although this will need to be evaluated with multiple isolates and parallel testing by ELISA.

The approach taken to validate the macroarray was to test for viruses in laboratory stocks and field isolates and to compare results with those obtained using serological techniques that represent the current standards in potato-testing programs. PCR-based techniques offer greater sensitivity; however, because of the additional handling requirements (nucleic acid extraction), ELISA remains the primary technique employed. It should be noted that the field isolates tested (Table 2) were not current-season samples but, rather, were diseased plant samples that had been placed into tissue culture in order to maintain the potato cultivar and viruses. Although viruses can be lost in plants in tissue culture, samples of the same stock were sampled in parallel for both ELISA and the macroarray.

There were several properties of the macroarray particularly encouraging with regard to its ultimate utility. One has been the ease in interpreting results, in part due to the reproducible absence of spurious hybridization to probes by targets prepared from uninfected plants. Uninfected plantderived sequences did reproducibly hybridize to probe PVX-6 and usually to PVX-4 but, rather, than being confounding, it was expected and provided a useful landmark to interpret other hybridization signals. Another factor contributing to the ease of interpretation has been that when virus-specific hybridization did occur, it was observed with multiple, spatially clustered, virus-specific probes, making interpretation unambiguous. A third useful feature of the macroarray has been that many pathogens can be detected simultaneously without any apparent interference, up to four viruses (Fig. 3) or two viruses and PSTV (Fig. 4).

The strength of hybridization signals in the macroarray is a function of many factors: the design and specific sequence of each oligonucleotide, infected-plant virus RNA concentration, and viral RNA size and secondary structure that, in turn, affect the efficiency of the cDNA synthesis before PCR amplification. By using a sufficient number of probes, there should not be any impediment to the detection of a virus in a macroarray, so long as sufficient sequence information is available for probe design and virus titers are not lower than the viruses in this study. Even in the case of emerging viruses that have not been sequenced, detection may be possible if there is sufficient genome sequence conservation within the family. This is illustrated by results for detecting carlaviruses, where labeled targets from PVM- and PotLV-infected plants hybridized with at least one PVS probe. The larger the number of conserved blocks of sequences within a genus and corresponding probes used in an array, the greater the likelihood of detecting related but uncharacterized viruses.

The most challenging aspect of this study was to facilitate the detection of viroid sequences in combination with an infecting virus. Although cDNA synthesis was primed with random pentamers, some biased products have been observed (2), and PSTV sequences were not effectively detected without viroid-specific primers (Fig. 5). The basis for this may have been a low concentration of viroid RNA or an inefficient synthesis of viroid cDNAs in the RT reaction step, perhaps due to the small size of PSTV (359 nucleotides). This problem was overcome through the inclusion of viroid-specific primers at the amplification step. The viroid-specific primer pair P439/P440 may prove useful for the detection of other viroids, because sequence analyses suggest that these primers will amplify other viroids from solanaceous crops, with 9 and 11 of the $3^{\prime}$ terminal contiguous nucleotides of P439 and $\mathrm{P} 440$, respectively, being identical to sequences of eight pospiviroids (data not shown).

In conclusion, the described potato macroarray compliments existing serological technologies (ELISA configurations) and holds great potential for detecting viruses not commonly tested for. However, in its current form, it is not recommended as a replacement for ELISA. Certainly in a region with a limited number of naturally occurring viruses in potato, one would want to continue to use immunoassays that have proven to be very effective. However, depending upon the concentration of virus in the infected plant or the antibodies being used in the assay, ELISA results are sometimes at threshold levels and difficult to interpret. This is particularly apparent in testing for the presence of virus in dormant tubers or in sprouts from tubers where virus may be at low concentrations and difficult to detect by ELISA. It will be interesting to employ macroarrays for the testing of dormant and spouted tubers, and this will be especially useful if done in parallel with serological assays. Increasing the sensitivity of virus detection will certainly make array-based diagnostics more attractive and, perhaps, reliable.

In the long term, the greater significance of the described technology is the potential to develop macroarrays for the detection of scores of viruses and all pathogens of a specific crop (e.g., potato) or group of crops (e.g., solanaceous plants). Relative to microarrays, this type of multipathogen detection system should prove to be cost effective and may be accessible to a broader range of diagnostic laboratories.

\section{ACKNOWLEDGMENTS}

This research was supported by United States Department of Agriculture-NRI program grant no. 2004-35605-14325 to K. L. Perry. We thank C. Smart, N. Zhang, A. Charkowski, and J. Thompson for assistance in the development of the detection system; A. Lesvesque for protocols and advice; J. Volkonen and J. Aura for providing PMTV samples; J. Crosslin for providing TRV samples; and L. Miller for technical support.

\section{LITERATURE CITED}

1. Abdullahi, I., Koerbler, M., Stachewicz, H., and Winter, S. 2005. The 18S rDNA sequence of Synchytrium endobioticum and its utility in microarrays for the simultaneous detection of fungal and viral pathogens of potato. Appl. Microbiol. Biotechnol. 68:368-375.

2. Agindotan, B., and Perry, K. L. 2007. Macroarray detection of plant RNA viruses using randomly primed and amplified complementary DNAs from infected plants. Phytopathology 97:119-127.

3. Altschul, S. F., Madden, T. L., Schaffer, A. A., Zhang, J. H., Zhang, Z., Miller, W., and Lipman, D. J. 1997. Gapped BLAST and PSIBLAST: a new generation of protein database search programs. Nucleic Acids Res. 25:33893402.

4. Boonham, N., Walsh, K., Smith, P., Madagan, K., Graham, I., and Barker, I. 2003. Detection of potato viruses using microarray technology: towards a generic method for plant viral disease diagnosis. J. Virol. Methods 108:181-187.

5. Brattey, C., Badge, J. L., Burns, R., Foster, G. D., George, E., Goodfellow, H. A., Mulhol- 
land, V., McDonald, J. G., and Jeffries, C. J. 2002. Potato latent virus: a proposed new species in the genus Carlavirus. Plant Pathol. 51:495-505.

6. Bystricka, D., Lenz, O., Mraz, I., Dedic, P., and Sip, M. 2003. DNA microarray: parallel detection of potato viruses. Acta Virol. 47:4144.

7. Bystricka, D., Lenz, O., Mraz, I., Pilterova, L., Kmoch, S., and Sip, M. 2005. Oligonucleotide-based microarray: A new improvement in microarray detection of plant viruses. J. Virol. Methods 128:176-182.

8. Cavileer, T. D., Clarke, R. C., Corsini, D. L., and Berger, P. H. 1998. A new strain of potato carlavirus M. Plant Dis. 82:98-102.

9. Chiu, C. Y., Rouskin, S., Koshy, A., Urisman, A., Fischer, K., Yagi, S., Schnurr, D., Eckburg, P. B., Tompkins, L. S., Blackburn, B. G., Merker, J. D., Patterson, B. K., Ganem, D., and DeRisi, J. L. 2006. Microarray detection of human parainfluenzavirus 4 infection associated with respiratory failure in an immunocompetent adult. Clin. Infect. Dis. 43:E71E76.

10. Crosslin, J. M., Thomas, P. E., and Brown, C. R. 1999. Distribution of Tobacco rattle virus in tubers of resistant and susceptible potatoes and systemic movement of virus into daughter plants. Am. J. Potato Res. 76:191-197.

11. Deyong, Z., Willingmann, P., Heinze, C., Adam, G., Pfunder, M., Frey, B., and Frey, J. E. 2005. Differentiation of Cucumber mosaic virus isolates by hybridization to oligonucleotides in a microarray format. J. Virol. Methods 123:101-108.

12. Fessehaie, A., De Boer, S. H., and Levesque, C. A. 2003. An oligonucleotide array for the identification and differentiation of bacteria pathogenic on potato. Phytopathology 93:262269.

13. Francois, C., Kebdani, N., Barker, I., Tomlinson, J., Boonham, N., and CastagnoneSereno, P. 2006. Towards specific diagnosis of plant-parasitic nematodes using DNA oligonucleotide microarray technology: a case study with the quarantine species Meloidogyne chitwoodi. Mol. Cell. Probes 20:64-69.

14. Harrison, B. D., and Reavy, B. 2002. Potato mop-top virus. In: CMI/AAB Descriptions of Plant Viruses. J. Antoniw and M. J. Adams, eds. Association of Applied Biologists, Wellesbourne.

15. Harrison, B. D., and Robinson, D. J. 1978. The tobaraviruses. Adv. Virus Res. 23:25-77.

16. Hull, R. 2002. Mathew's Plant Virology, 4th ed. Academic Press, San Diego, CA.

17. Klaassen, C. H. W., Prinsen, C. F. M., de Valk, H. A., Horrevorts, A. M., Jeunink, M. A. F., and Thunnissen, F. 2004. DNA microarray format for detection and subtyping of human papillomavirus. J. Clin. Microbiol. 42:21522160.

18. Laassri, M., Chizhikov, V., Mikheev, M., Shchelkunov, S., and Chumakov, K. 2003. Detection and discrimination of orthopoxviruses using microarrays of immobilized oligonucleotides. J. Virol. Methods 112:67-78.

19. Lambert, D. H., Levy, L., Mavrodieva, V. A., Johnson, S. B., Babcock, M. J., and Vayda, M. E. 2003. First report of Potato mop-top virus on potato from the United States. Plant Dis. 87:872.

20. Lee, G. P., Min, B. E., Kim, C. S., Choi, S. H., Harn, C. H., Kim, S. U., and Ryu, K. H. 2003. Plant virus cDNA chip hybridization for detection and differentiation of four cucurbitinfecting tobamoviruses. J. Virol. Methods 110:19.

21. Levesque, C. A., Harlton, C. E., and de Cock, A. W. A. M. 1998. Identification of some oomycetes by reverse dot blot hybridization. Phytopathology 88:213-222.

22. Lievens, B., Brouwer, M., Vanachter, A., Levesque, C. A., Cammue, B. P. A., and Thomma, B. 2003. Design and development of a DNA array for rapid detection and identification of multiple tomato vascular wilt pathogens. FEMS Microbiol. Lett. 223:113-122.

23. Lin, B. C., Vora, G. J., Thach, D., Walter, E., Metzgar, D., Tibbetts, C., and Stenger, D. A. 2004. Use of oligonucleotide microarrays for rapid detection and serotyping of acute respiratory disease-associated adenoviruses. J. Clin. Microbiol. 42:3232-3239.

24. Martin, R. R., James, D., and Levesque, C. A. 2000. Impacts of molecular diagnostic technologies on plant disease management. Annu. Rev. Phytopathol. 38:207-239.

25. Mowat, W. P., and Dawson, S. 1987. Detection and identification of plant viruses by ELISA using crude sap extracts and unfractionated antisera. J. Virol. Methods 15:233-247.

26. Ramsay, G. 1998. DNA chips: state-of-the-art. Nat. Biotechnol. 16:40-44.

27. Saiki, R. K., Walsh, P. S., Levenson, C. H., and Erlich, H. A. 1989. Genetic-analysis of amplified DNA with immobilized sequence-specific oligonucleotide probes. Proc. Natl. Acad. Sci. USA 86:6230-6234.

28. Sholberg, P., O'Gorman, D., Bedford, K., and Levesque, C. A. 2005. Development of a DNA macroarray for detection and monitoring of economically important apple diseases. Plant Dis. 89:1143-1150.

29. Slack, S. A. 1993. Seed certification and seed improvement programs. Pages 61-65 in: Potato Health Management. R. C. Rowe, ed. American Phytopathological Society Press, St. Paul $\mathrm{MN}$.

30. Slack, S. A., and Tufford, L. A. 1995. Meristem culture for virus elimination. Pages 117 128 in: Fundamental Methods of Plant Cell, Tissue and Organ Culture and Laboratory Operations. O. L. Gamborg and G. C. Phillips, eds. Springer-Velag, Berlin.

31. Tambong, J. T., de Cock, A., Tinker, N. A., and Levesque, C. A. 2006. Oligonucleotide array for identification and detection of Pythium species. Appl. Environ. Microbiol. 72:26912706.

32. Troesch, A., Nguyen, H., Miyada, C. G., Desvarenne, S., Gingeras, T. R., Kaplan, P. M. Cros, P., and Mabilat, C. 1999. Mycobacterium species identification and rifampin resistance testing with high-density DNA probe arrays. J. Clin. Microbiol. 37:49-55

33. Wang, D., Coscoy, L., Zylberberg, M., Avila, P. C., Boushey, H. A., Ganem, D., and DeRisi, J. L. 2002. Microarray-based detection and genotyping of viral pathogens. Proc. Natl. Acad. Sci. USA 99:15687-15692.

34. Wang, D., Urisman, A., Liu, Y. T., Springer, M., Ksiazek, T. G., Erdman, D. D., Mardis, E. R., Hickenbotham, M., Magrini, V., Eldred, J., Latreille, J. P., Wilson, R. K., Ganem, D., and DeRisi, J. L. 2003. Viral discovery and sequence recovery using DNA microarrays. PLoS Biol. 1:257-260.

35. Webb, R. E. 1958. Schultz potato virus collection. Am. Potato J. 35:615-619.

36. Wilson, W. J., Strout, C. L., DeSantis, T. Z., Stilwell, J. L., Carrano, A. V., and Andersen, G. L. 2002. Sequence-specific identification of 18 pathogenic microorganisms using microarray technology. Mol. Cell. Probes 16:119-127.

37. Xu, H., DeHaan, T.-L., and De Boer, S. H. 2004. Detection and confirmation of Potato mop-top virus in potatoes produced in the United States and Canada. Plant Dis. 88:363367. 